\title{
Citric acid production from glucose by yeast Candida oleophila ATCC 20177 under batch, continuous and repeated batch cultivation
}

\author{
Savas Anastassiadis*\# \\ Research in Biotechnology, Co. \\ Vat. \#: 108851559. Avgi/Sohos \\ 57002 Thessaloniki, Greece \\ Tel: 302395051324 \\ Fax: 302395051470 \\ E-mail: sanastassiadis@netscape.net \\ Hans-Jürgen Rehm \\ Institute of Molecular Microbiology and Biotechnology \\ University of Münster \\ Corrensstr. 3, 48149 Münster, Germany \\ (retired Professor) \\ http://www.greekbiotechnologycenter.gr
}

\begin{abstract}
Financial support: The work has been carried out at the Institute of Biotechnology 2 of Research Centre Jülich (Germany) and was financed by Haarmann
\end{abstract} and Reimer, a daughter company of the company Bayer, Leverkusen, Germany.

\begin{abstract}
Keywords: air saturation influence, chemostat, citric acid, citric acid fermentation, repeated batch, oxygen influence. 2395-051470, E-mail: sanastassiadis@netscape.net.

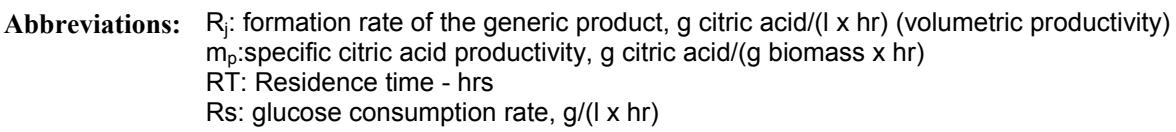

Present address: ${ }^{*}$ Research in Biotechnology, Co., Vat. 108851559. Avgi/Sohos, 57002 Thessaloniki, Greece; Tel. +30-2395-051324; Tel./Fax. +30-

The effect of air saturation on citric acid production in batch, repeated batch and chemostat cultures has been studied. It was shown that, under continuous fermentation (chemostat mode), the highest concentration of citric acid equal of $98 \mathrm{~g} / \mathrm{l}$ was produced at $20 \%$ of air saturation. In contrary to continuous fermentation, displaying an optimum at $20 \%, 80 \%$ air saturation yielded higher values in repeated batch fermentation process. $167 \mathrm{~g} / \mathrm{l}$ citric acid were produced continuously with the fill and drain technique at 4.85 days, at $80 \%$ air saturation, compared with $157.6 \mathrm{~g} / \mathrm{l}$ achieved within 5.4 days at $20 \%$. Under repeated batch fermentation, the formation rate of the generic product $(\mathrm{Rj})$ as well as the specific citric acid productivity $\left(\mathrm{m}_{\mathrm{p}}\right)$ reached a maximum of $1.283 \mathrm{~g} /(\mathrm{l} \times \mathrm{hr})$ at 4.01 days and of $0.0375 \mathrm{~g} /(\mathrm{g} \times \mathrm{hr})$ at 4.58 days, respectively. The glucose consumption rate $(\mathrm{Rx})$ reached a maximum value of $3.33 \mathrm{~g} /(\mathbf{l} \times \mathrm{hr})$ entering stationary phase after 2.56 days at a glucose concentration of $131.2 \mathrm{~g} / \mathrm{l}$.

Citric acid is an important multifunctional organic acid with a broad range of versatile uses in household and industrial applications that has been produced industrially since the beginning of $20^{\text {th }}$ century. Several hundreds of thousands metric tons of citric acid are produced worldwide every year almost exclusively by fermentation. Although processes involving yeasts of genera Candida have been well described, which can produce large amounts of citric acid, industry still employs selected strains of Aspergillus niger. However, yeast processes are also sporadically used in industry today.

Formation of citric and isocitric acid by yeasts using various $\mathrm{C}$-sources has been the focus of investigations in different aspects for the past 35 years. Most reports are devoted to various types of citric acid producing yeasts and to experimental conditions governing production of citric acid, essentially based on shake flasks assays under undefined fermentation conditions. Only a few optimisation studies have been carried out in stirred fermenters. Continuous operation for the production of citric acid by yeasts, using glucose or other carbon sources, have increasingly received research interest in the last years; however the yields achieved were not high enough for a competitive economic industrial operation (Enzminger and Asenjo, 1986; Kim et al. 1987; Klasson et al. 1989; Kim and Roberts, 1991; Bubbico et al. 1996; Arzumanov et al. 2000; Anastassiadis et al. 2005; Anastassiadis and Rehm, 2005).

Yarrowia lipolytica and other Candida species are capable of producing citric acid using various carbon sources and

*Corresponding author 

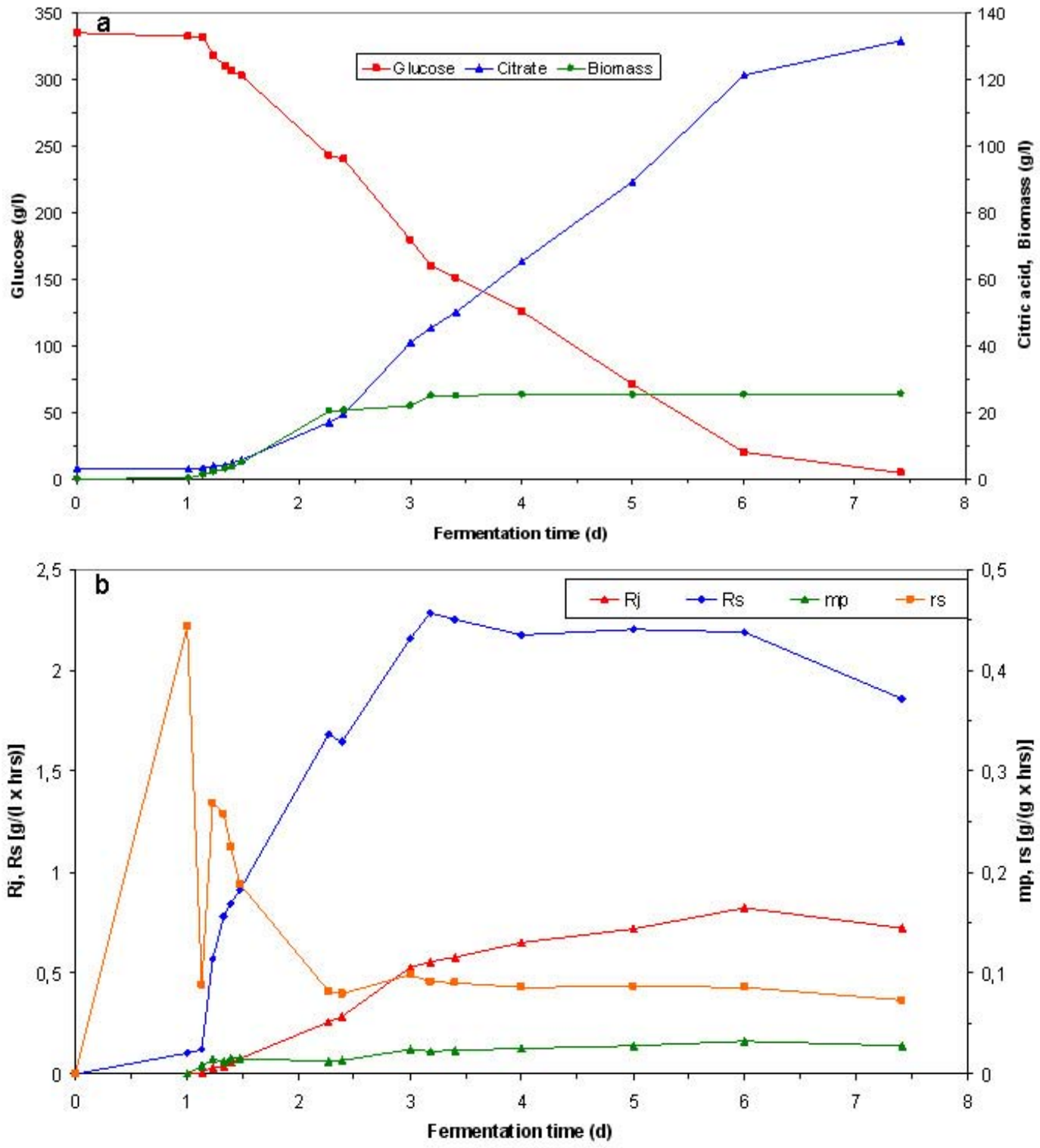

Figure 1. Initial batch fermentation of citric acid by Candida oleophila.

(a) Glucose, citric acid and biomass as a function of fermentation time.

(b) Formation rate of the generic product $(\mathrm{Rj})$, specific citric acid productivity $\left(\mathrm{m}_{\mathrm{p}}\right)$ and glucose consumption rate $(\mathrm{Rs})$ and specific glucose consumption rate $\left(\mathrm{r}_{\mathrm{s}}\right) ;\left(30^{\circ} \mathrm{C}, \mathrm{pH} 4.5\right)$.

substrates (Hattori et al. 1974; Ilarionowa et al. 1975; Furukawa et al. 1977; Behrens et al. 1978; Lozinov and Finogenova, 1982; Stottmeister et al. 1986; Stottmeister and Hoppe, 1991; Anastassiadis et al. 1993; Anastassiadis, 1994; Anastassiadis et al. 1994; Moresi, 1994; Mayilvahanan et al. 1996; Tisnadjaja et al. 1996; Anastassiadis et al. 2001; Kamzolova et al. 2003; Anastassiadis et al. 2005), whereby glucose has increasingly received interest after the oil crisis of 1973, a situation very actual today as well. Candida oleophila ATCC 20177 (var.) (obtained from Dr. Siebert) had been identified and selected under many yeast strains for the development of a new competitive fermentation process for continuous citric acid production. C. oleophila does not form mycelia, has a well-developed TCA-cycle and can overproduce citric acid continuously in very high yields from various carbon sources. It showed good stability in continuous chemostat operations over a long time of several months (Anastassiadis et al. 1993; Anastassiadis, 1994; Anastassiadis et al. 1994; Anastassiadis et al. 2001; Anastassiadis et al. 2002; Anastassiadis et al. 2005; Anastassiadis and Rehm, 2005).

Optima air concentration of more than $50 \%$ and up to 60 ppm are reported abroad in international literature for discontinuous citric acid processes utilizing yeast strains (Stottmeister et al. 1981; Okoshi et al. 1987). Increasing aeration intensity and agitation rate has been reported to 

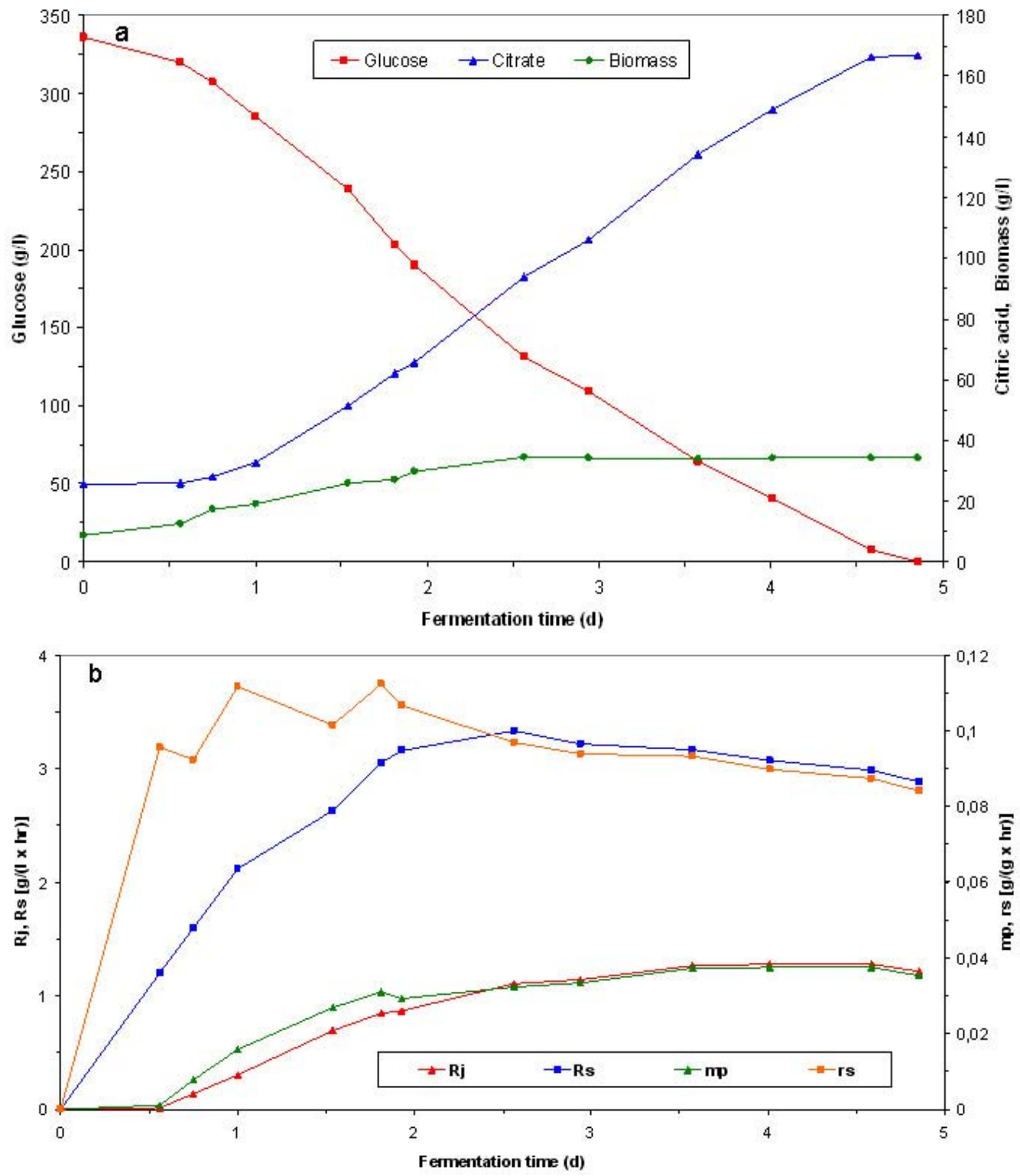

Figure 2. Repeated batch fermentation $\left(\mathrm{RB}_{1}\right)$ of citric acid with Candida oleophila at $80 \%$ air saturation.

(a) Glucose, citric acid and biomass as a function of fermentation time.

(b) Formation rate of the generic product $(\mathrm{Rj})$, specific citric acid productivity $\left(\mathrm{m}_{\mathrm{p}}\right)$, glucose consumption rate (Rs) and specific glucose consumption rate $\left(r_{\mathrm{s}}\right) ;\left(30^{\circ} \mathrm{C}, \mathrm{pH} 5\right)$.

influence positively citric acid production in various yeast strains utilizing $n$-paraffin as carbon source (Hattori et al. 1974; Ilarionowa et al. 1975; Furukawa et al. 1977). Marchal et al. (1977) didn't find any further increase of citrate production rate in Saccharomycopsis lipolytica at air saturations higher than $40 \%$ utilizing $n$-paraffins. An affinity constant for oxygen of $\mathrm{K}_{\mathrm{s}}=0.8 \times 10^{-5} \mathrm{M}$ has been cited. Briffaud and Engasser (1979) found, using glucose as carbon source, a dependency of citrate excretion in Saccharomycopsis lipolytica upon oxygen partial pressure, following a Michaelis-Menten kinetic with a $\mathrm{K}_{\mathrm{s}}$ of $2.8 \times 10^{-}$ 5 M. Furthermore, Tabuchi (1973) reported about decreasing citric acid production and the occurrence of true septa under oxygen deficiency, whereby aeration was the only factor triggering out cell dimorphism. Enzminger and Asenjo (1986) reported about a minimum value of $10 \%$ air saturation, necessary for continuing citric acid production. Consumption rate of oxygen has been reported to decrease during the first hours of production phase (idiophase) and remains constant for a long period of about $100 \mathrm{hrs}$ until it decreases again asymptotically (Stottmeister et al. 1981), in correlation with the coarse of specific values (Behrens et al. 1977) and of activities of TCA enzymes (Franke-Rinker and Behrens, 1979). Kamzolova et al. (2003) reported about the dependency of oxygen requirements for growth and citric acid synthesis in chemostat cultures of $Y$. 
Table 1. Citric acids and biomass concentration, generic product formation rate and specific citric acid productivity as a function of air saturation.

\begin{tabular}{|l|c|c|c|c|c|}
\hline \multirow{2}{*}{ Parameters } & \multicolumn{5}{c|}{ Air saturation (\%) } \\
\cline { 2 - 6 } & 5 & 20 & 50 & 80 & 133 \\
\hline Biomass, (g/l) & 21.3 & 18.09 & 25.15 & 29.62 & 18.77 \\
\hline Citric acid, (g/l) & 77.18 & 98.24 & 78.03 & 77.3 & 71.37 \\
\hline Isocitric acid, (g/l) & 2.54 & 2.954 & 3.06 & 2.797 & 2.613 \\
\hline Generic product, g/(I x hr) & 1.39 & 1.81 & 1.41 & 1.41 & 1.276 \\
\hline $\begin{array}{l}\text { Specific citric acid productivity, g/(g x } \\
\text { hr) }\end{array}$ & 0.0633 & 0.1 & 0.0565 & 0.0477 & 0.0679 \\
\hline
\end{tabular}

lipolytica on the iron concentration in medium and about an increase of biomass at increasing air saturation from $5 \%$ to $60 \%$ at low iron concentration $(0.7 \mathrm{mg} / \mathrm{l})$, whereas no effect was found at higher iron concentration. Citric acid production increased at low iron concentration increasing air saturation from $5 \%$ to $60 \%$ and no effect was found at increasing air saturation from $20 \%$ to $60 \%$ at high iron concentration (Kamzolova et al. 2003). This effect could also be influenced by the effect of air saturation, because at $20 \%$ air saturation the highest citric acid concentration of $98.2 \mathrm{~g} / \mathrm{l}$ (compared with only about $77 \mathrm{~g} / \mathrm{l}$ or $79 \mathrm{~g} / \mathrm{l}$ at $5 \%$ or $60 \%$ air saturation, respectively) and maximum citrate secretion by the specific active transport system have been obtained in chemostat cultures without any iron addition into the medium. Traces of iron that are present in other chemical compounds (contaminant) fulfil the microorganism's requirement (Anastassiadis et al. 1993; Anastassiadis, 1994; Anastassiadis et al. 2001; Anastassiadis and Rehm, 2005). Stottmeister et al. (1986) reported regarding a changing air saturation profile during the course of citric acid fermentation by yeasts in an interesting way. Air saturation between 50 and $90 \%$ was applied during first growth phase until reaching about $75 \%$ of final biomass concentration, followed up by a reduction of air saturation during second growth phase to limiting values below $10 \%$, preferably around $1 \%$, resulting to shortening time of transition phase occurring between growth (trophophase) and production phase (idiophase). Finally, air saturation was set at values between 30 and $90 \%$ at the beginning and during entire time of production phase (Stottmeister et al. 1986). About the positive effect of a two-stage oxygen supply control strategy on pyruvate production by Torulopsis glabrata using changing agitation speed has been reported by $\mathrm{Li}$ et al. (2002). Enormous increase in citrate production rates of Aspergillus niger has also been reported to occur by increasing aeration intensity (Khan and Ghose, 1973), applying pure oxygen (Kristiansen and Sinclair, 1978) and increasing oxygen concentrations between 40-150 mbar (corresponds to about $18.6-70.5 \%$ of air saturation) (Kubicek et al. 1980). About a significant increase of production rates in single stage continuous cultures of $A$. foetidus has been reported by Kristiansen and Sinclair (1979) supplying pure oxygen instead of air, indicating a raising production of citric acid at increasing dissolved oxygen concentration, whereas dry weight remained relatively constant within a range between
0.07 and $0.30 \mathrm{~atm}$, instead. About the involvement of an alternative respiration chain in citric acid fermentation of $A$. niger reported Zehentgruber et al. 1980.

The object of the present work is to examine the air saturation influence on repeated batch fermentation of citric acid and to compare it with continuous and batch fermentation. A new developed fermentation process is presented as an alternative innovative approach that appears suitable and commercially valid for continuous industrial production of citric acid by yeasts.

\section{MATERIALS AND METHODS}

\section{Microorganism}

Candida oleophila ATCC 20177 var. (obtained from Dr. Siebert, Jungbunzlauer Co. and later Haarmann and Reimer, a daughter company of Bayer Co., Leverkusen, Germany) was used through all of experiments in present work, which was selected under many yeast strains during an extensive screening program (Anastassiadis et al. 1993; Anastassiadis, 1994; Anastassiadis et al. 1994; Anastassiadis et al. 2001; Anastassiadis et al. 2002; Anastassiadis et al. 2005). Yeast malt extract agar plates (YME) inoculated with C. oleophila were incubated for 2-3 days and stored at $4^{\circ} \mathrm{C}$. Cultures were refreshed every 2-3 months. The inoculums (10\%) were prepared by transferring of cells from agar plates into $500 \mathrm{ml}$ shake flasks with buffels on a medium containing (g/l): $6 \mathrm{~g} / \mathrm{l}$ $\mathrm{NH}_{4} \mathrm{Cl}, 30 \mathrm{~g} / \mathrm{l}$ glucose, $1.05 \mathrm{~g} / \mathrm{l} \mathrm{KH}_{2} \mathrm{PO}_{4}, 1.4788 \mathrm{~g} / \mathrm{l} \mathrm{MgSO}$ x $7 \mathrm{H}_{2} \mathrm{O}, 0.33435 \mathrm{~g} / \mathrm{l} \mathrm{MnSO}_{4}$ x $4 \mathrm{H}_{2} \mathrm{O}, 0 \mathrm{~g} / \mathrm{FeSO}_{4}$ x $7 \mathrm{H}_{2} \mathrm{O}, 4$ $\mathrm{mg} / \mathrm{l} \mathrm{CuSO} \mathrm{Cu}_{4} \times 5 \mathrm{H}_{2} \mathrm{O}, 0.0839 \mathrm{~g} / \mathrm{l} \mathrm{ZnSO}_{4} \times 7 \mathrm{H}_{2} \mathrm{O}, 8 \mathrm{mg} / \mathrm{l}$ $\mathrm{CoSO}_{4} \times 7 \mathrm{H}_{2} \mathrm{O}, 0.08 \mathrm{~g} / \mathrm{l} \mathrm{H}_{3} \mathrm{BO}_{3}, 0.2 \mathrm{~g} / \mathrm{l} \mathrm{CaCl}, 0.2 \mathrm{~g} / \mathrm{l} \mathrm{NaCl}$, $0.2 \mathrm{mg} / \mathrm{l} \mathrm{KJ}, 0.4 \mathrm{mg} / \mathrm{l} \mathrm{Na} \mathrm{MoO}_{4} \times 2 \mathrm{H}_{2} \mathrm{O}, 2.5 \mathrm{~g} / \mathrm{l}$ citric acid, $4 \mathrm{mg} / \mathrm{l}$ Thiamine-HCl, $0.5 \mathrm{mg} / \mathrm{l}$ Biotin, $1.25 \mathrm{mg} / \mathrm{l}$ Pyridoxine- $\mathrm{HCl}, 1.25 \mathrm{mg} / \mathrm{l}$ Ca-D-Pantothenate, $1 \mathrm{mg} / \mathrm{l}$ Nicotinic acid. The shake flasks were incubated for 1 day at $30^{\circ} \mathrm{C}$ and $200 \mathrm{rpm}$.

\section{Chemostat experiments}

Cells were grown in a 21 fermenter (Biostat E, BraunDiessel) with the working volume of 1.91 in chemostat mode on a basal medium containing (g/l): $250 \mathrm{~g} / \mathrm{l}$ glucose,

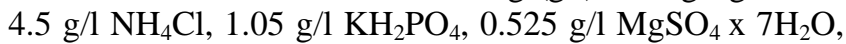
$0.2507 \mathrm{~g} / \mathrm{l} \mathrm{MnSO}_{4} \times 4 \mathrm{H}_{2} \mathrm{O}, 0 \mathrm{~g} / \mathrm{l} \mathrm{FeSO}{ }_{4} \times 7 \mathrm{H}_{2} \mathrm{O}, 0.15 \mathrm{mg} / \mathrm{l}$ 

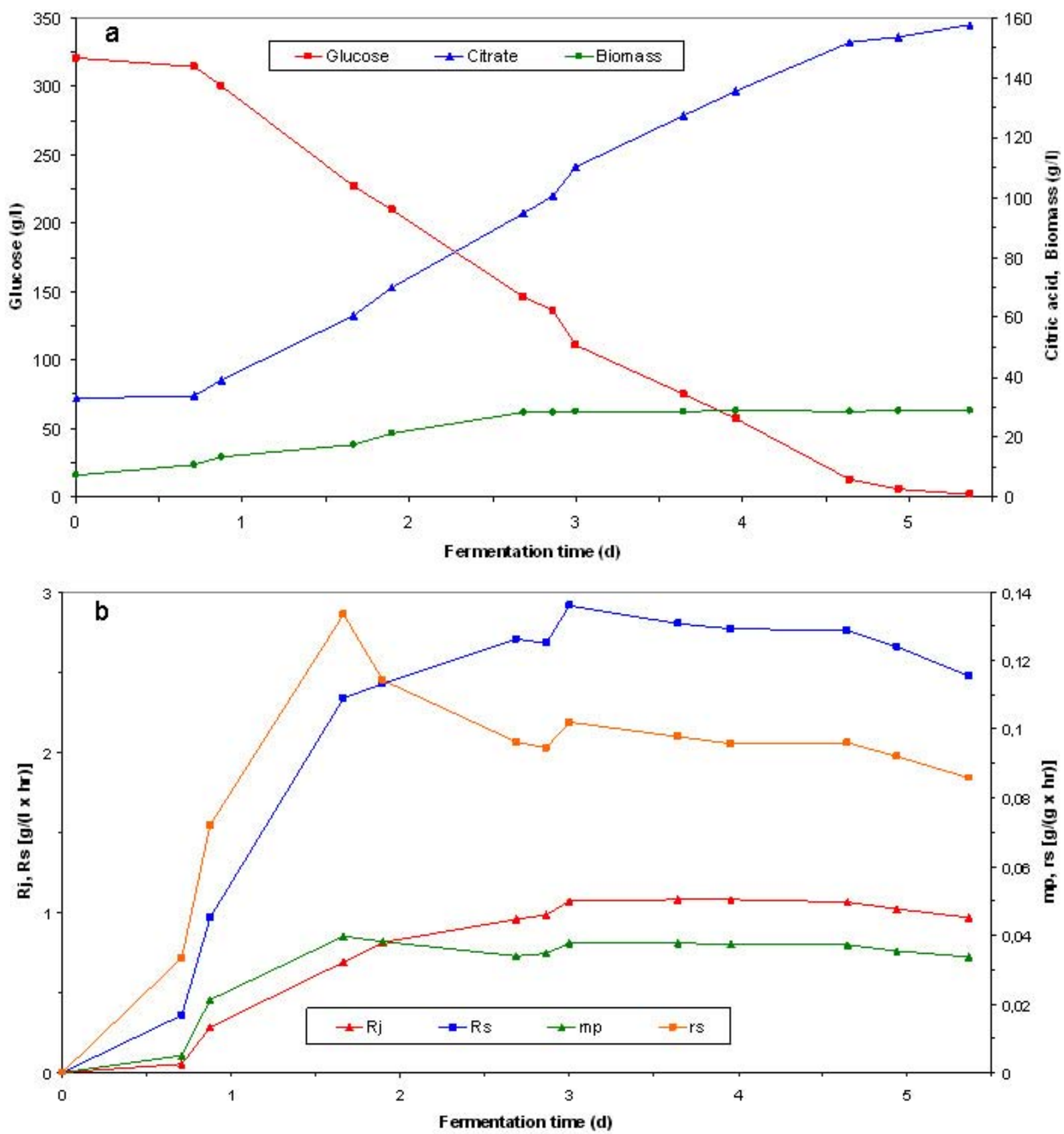

Figure 3. Repeated batch fermentation $\left(\mathrm{RB}_{1}\right)$ of citric acid with Candida oleophila at $20 \%$ air saturation.

(a) Glucose, citric acid and biomass as a function of fermentation time.

(b) Formation rate of the generic product $(\mathrm{Rj})$, specific citric acid productivity $\left(\mathrm{m}_{\mathrm{p}}\right)$, glucose consumption rate (Rs) and specific glucose consumption rate $\left(\mathrm{r}_{\mathrm{s}}\right) ;\left(30^{\circ} \mathrm{C}\right.$ and $\left.\mathrm{pH} 5\right)$.

$\mathrm{CuSO}_{4} \times 5 \mathrm{H}_{2} \mathrm{O}, 0.0315 \mathrm{~g} / \mathrm{ZnSO}_{4} \times 7 \mathrm{H}_{2} \mathrm{O}, 6 \mathrm{mg} / \mathrm{l} \mathrm{CoSO}_{4} \times$ $7 \mathrm{H}_{2} \mathrm{O}, 0.06 \mathrm{~g} / \mathrm{H}_{3} \mathrm{BO}_{3}, 0.15 \mathrm{~g} / \mathrm{l} \mathrm{CaCl}, 0.15 \mathrm{~g} / \mathrm{l} \mathrm{NaCl}, 0.15$ $\mathrm{mg} / \mathrm{l} \mathrm{KJ}, 2.5 \mathrm{~g} / \mathrm{l}$ citric acid, $0.3 \mathrm{mg} / 1 \mathrm{Na}_{2} \mathrm{MoO}_{4} \times 2 \mathrm{H}_{2} \mathrm{O}, 3$ $\mathrm{mg} / \mathrm{l}$ Thiamine-HCl, $0.375 \mathrm{mg} / \mathrm{l}$ Biotin, $0.9375 \mathrm{mg} / \mathrm{l}$ Pyridoxine- $\mathrm{HCl}, 0.9375 \mathrm{mg} / \mathrm{l} \mathrm{Ca}-\mathrm{D}-$ Pantothenate, $0.75 \mathrm{mg} / \mathrm{l}$ Nicotinic acid. Vitamins and $\mathrm{NH}_{4} \mathrm{Cl}$ were added separately into autoclaved medium $\left(30-60 \mathrm{~min}\right.$ at $\left.121^{\circ} \mathrm{C}\right)$ by sterile filtration through $0.2 \mu \mathrm{m}$ filters (Sartorius filter, Göttingen Germany). In all cases, nitrogen was a limiting factor of yeast growth. The culture flow rate $\mathrm{D}$ was $0.0185 \mathrm{~h}^{-1}$. When the flow rate had achieved a stationary level, the cultivation in each mode was continued until the culture medium in fermenter was replaced five times. The culture medium temperature was maintained automatically at $30^{\circ} \mathrm{C}$. The culture medium $\mathrm{pH}$ was maintained at 4.5 by automatic titration with $45 \% \mathrm{NaOH}$. The $\mathrm{pO}_{2}$ level was maintained within $5-133 \%$ of saturation.

\section{Batch and repeated batch fermentations}


The repeated batch fermentation is an alternative form of operation for continuous citric acid production. At the end of batch fermentation a part of fermentation solution was kept in fermenter as starting inoculum (about $300 \mathrm{ml}$ corresponding to about $1 / 7$ of 21 working volume). The fermenter was filled to 21 with a new sterile fermentation medium and next repeated batch fermentation started immediately thereafter under controlled operation conditions. A fermentation medium as described in materials and methods was used with $6 \mathrm{~g} / \mathrm{l} \mathrm{NH}_{4} \mathrm{Cl}$ and 400 $\mathrm{g} / \mathrm{l}$ glucose (high osmotolerance of $C$. oleophila). Batch and repeated batch experiments (RB) were carried out at $20 \%$ or $80 \%$ air saturation, $30^{\circ} \mathrm{C}$, $\mathrm{pH} 4.5$ or 5 (optimum pH) and an agitation of $600 \mathrm{rpm}$. Each of repeated batch experiments was repeated several times and the best representing experiment for each particular fermentation conditions is presented here. The experiments were repeated as long as it was required for the repeated batch system to be stabilized and after this point the results were reproducible (a kind of steady state situation). This means that the inoculum left over from the initialization batch experiments doesn't represent the one of repeated batch fermentations. The starting values of RB experiments are the result from a previous $\mathrm{RB}$ experiment, reflecting the real situation of a series of repeated batch experiments In this case it will be unnecessary to combine the batch and repeated batch experiments. Possible differences occurring in starting data could be explained by the biomass that sticks on the fermenter vessel, which is difficult to avoid coming into the vessel during the filling procedure. About 20 repeated batch experiments were sequentially carried out without any technical and microbiological stability problems at $100 \%$ conversion, showing the stability and feasibility of the new fermentation process. The temperature was automatically controlled at set point of $30^{\circ} \mathrm{C}$ and $\mathrm{pH}$ at set point of 5 adding $45 \% \mathrm{NaOH}$, using a $\mathrm{pH}$ controller and a peristaltic pump (Biostat $\mathrm{E}$ fermenter, Braun-Diessel). During the entire duration of fermentation, $\mathrm{NaOH}$ consumption and physical parameters (e.g. $\mathrm{pH}$ of fermentation broth was periodically measured externally and corrected) were steadily followed up and evaluated.

\section{Culture conditions for batch and repeated batch experiments}

An extensively optimised fermentation medium of following composition was used during this work for batch and repeated batch experiments: $6 \mathrm{~g} / 1 \mathrm{NH}_{4} \mathrm{Cl}, 400 \mathrm{~g} / \mathrm{l}$ glucose, $1.05 \mathrm{~g} / \mathrm{l} \mathrm{KH}_{2} \mathrm{PO}_{4}, 1.4788 \mathrm{~g} / \mathrm{l} \mathrm{MgSO}_{4} \times 7 \mathrm{H}_{2} \mathrm{O}$, $0.33435 \mathrm{~g} / \mathrm{l} \mathrm{MnSO}_{4} \times 4 \mathrm{H}_{2} \mathrm{O}, 0 \mathrm{~g} / \mathrm{FeSO}_{4} \times 7 \mathrm{H}_{2} \mathrm{O}, 4 \mathrm{mg} / \mathrm{l}$ $\mathrm{CuSO}_{4} \times 5 \mathrm{H}_{2} \mathrm{O}, 0.0839 \mathrm{~g} / \mathrm{Z} \mathrm{ZnSO}_{4} \times 7 \mathrm{H}_{2} \mathrm{O}, 8 \mathrm{mg} / \mathrm{l} \mathrm{CoSO} \mathrm{C}_{4} \mathrm{X}$ $7 \mathrm{H}_{2} \mathrm{O}, 0.08 \mathrm{~g} / \mathrm{l} \mathrm{H}_{3} \mathrm{BO}_{3}, 0.2 \mathrm{~g} / \mathrm{l} \mathrm{CaCl}{ }_{2}, 0.2 \mathrm{~g} / \mathrm{l} \mathrm{NaCl}, 0.2 \mathrm{mg} / \mathrm{l}$ $\mathrm{KJ}, 0.4 \mathrm{mg} / 1 \mathrm{Na}_{2} \mathrm{MoO}_{4} \times 2 \mathrm{H}_{2} \mathrm{O}, 2.5 \mathrm{~g} / \mathrm{l}$ citric acid, $4 \mathrm{mg} / \mathrm{l}$ Thiamine- $\mathrm{HCl}, 0.5 \mathrm{mg} / \mathrm{l}$ Biotin, $1.25 \mathrm{mg} / \mathrm{l}$ Pyridoxine- $\mathrm{HCl}$, $1.25 \mathrm{mg} / \mathrm{l}$ Ca-D-Pantothenate, $1 \mathrm{mg} / \mathrm{l}$ Nicotinic acid. Vitamins and $\mathrm{NH}_{4} \mathrm{Cl}$ were added separately into autoclaved medium (sterilized for $30-60 \mathrm{~min}$ at $121^{\circ} \mathrm{C}$ ) by sterile filtration through $0.2 \mu \mathrm{m}$ filters (Sartorius filter, Göttingen Germany) (Anastassiadis et al. 2005). Any variations in element concentrations and media composition are given in results section. Silicon oil or polypropylene glycol was used as antifoaming agent.

\section{Air saturation}

The air saturation (\%) was measured using a galvanic electrode (type Ingold) and $\mathrm{pO}_{2}$ instrument (type $\mathrm{O}_{2^{-}}$ amplifier, Endress \& Hauser $\mathrm{GmbH}$ ). Air saturation was on line monitored and values were transferred to a computer program (MEAS, Research Centre Jülich, Germany).

Air saturation was adjusted to $100 \%$ using atmospheric air at $1 \mathrm{vvm}$ flow rate, $1000 \mathrm{rpm}$ agitation, $30^{\circ} \mathrm{C}$ and $\mathrm{pH} 4.5$ in sterilized fermentation medium. The $0 \%$ value was adjusted using $1 \mathrm{vvm}$ nitrogen gas. For achieving constant air saturation at set point (e.g. $80 \%$ or $20 \%$ ), airflow rate was held constant at $0.5 \mathrm{vvm}$, whereas pure oxygen was automatically added into atmospheric air using a magnetic valve driven by an automatic oxygen control unit. Sterile air filters with $0.2 \mu \mathrm{m}$ pores were used for air and oxygen transfer into fermenter. This setting of air saturation control was found to be best solution for keeping constant air saturation over a very long period of time (Anastassiadis et al. 1993; Anastassiadis, 1994; Anastassiadis et al. 1994; Anastassiadis et al. 2001).

\section{Analysis}

Optical density $\left(\mathrm{OD}_{660 \mathrm{~nm}}\right)$ and dry biomass (filter method) were measured as described in Anastassiadis et al. 2002. Organic acids, glucose, ammonia nitrogen and intracellular concentrations were analysed as described in Anastassiadis, 1993; Anastassiadis et al. 1993; Anastassiadis et al. 1994; Anastassiadis et al. 2001; Anastassiadis et al. 2002; Anastassiadis et al. 2005. HPLC methods were developed in order to achieve a separation between the chemically related compound citric acid and isocitric acid or glucose and gluconic acid (Anastassiadis, 1993, Anastassiadis et al. 1993; Anastassiadis et al. 1994; Anastassiadis et al. 1999; Anastassiadis et al. 2001). A solvent with $5 \mathrm{mM}$ TBA (tetra-butyl-ammonium hydrogen sulphate) in an aqueous solution of $2 \%$ acetonitrile was used as mobile phase at a flow rate of $1 \mathrm{ml} / \mathrm{min}$. The eluent was degassed using helium gas before each measurement. The column temperature was kept at $37^{\circ} \mathrm{C}$. An $5 \mathrm{C}_{18} \mathrm{AB}$ column (Macherey and Nagel, Düren, Germany) was used as stationary phase. A pressure of $0.4-0.5$ bar was applied in the eluent bottle using helium gas. The substances were detected by a UV detector at $210 \mathrm{~nm}$ and the concentrations were evaluated by a computer program (AXXIOM). The same HPLC method was also used later by Antonucci et al. 2001 for the separation and analysis of chemically related citric and isocitric acid without any reference to above method. For glucose analysis, an isocratic HPLC application was developed in order to separate glucose from gluconic acid. A Nucleosil $\mathrm{NH}_{2} 10 \mu(250 \times 4)$ column and a mobile phase with $75 \%$ acetonitrile (in $25 \%$ water) were used at $37^{\circ} \mathrm{C}$ or higher and $1-1.5 \mathrm{ml} / \mathrm{min}$ flow rate 

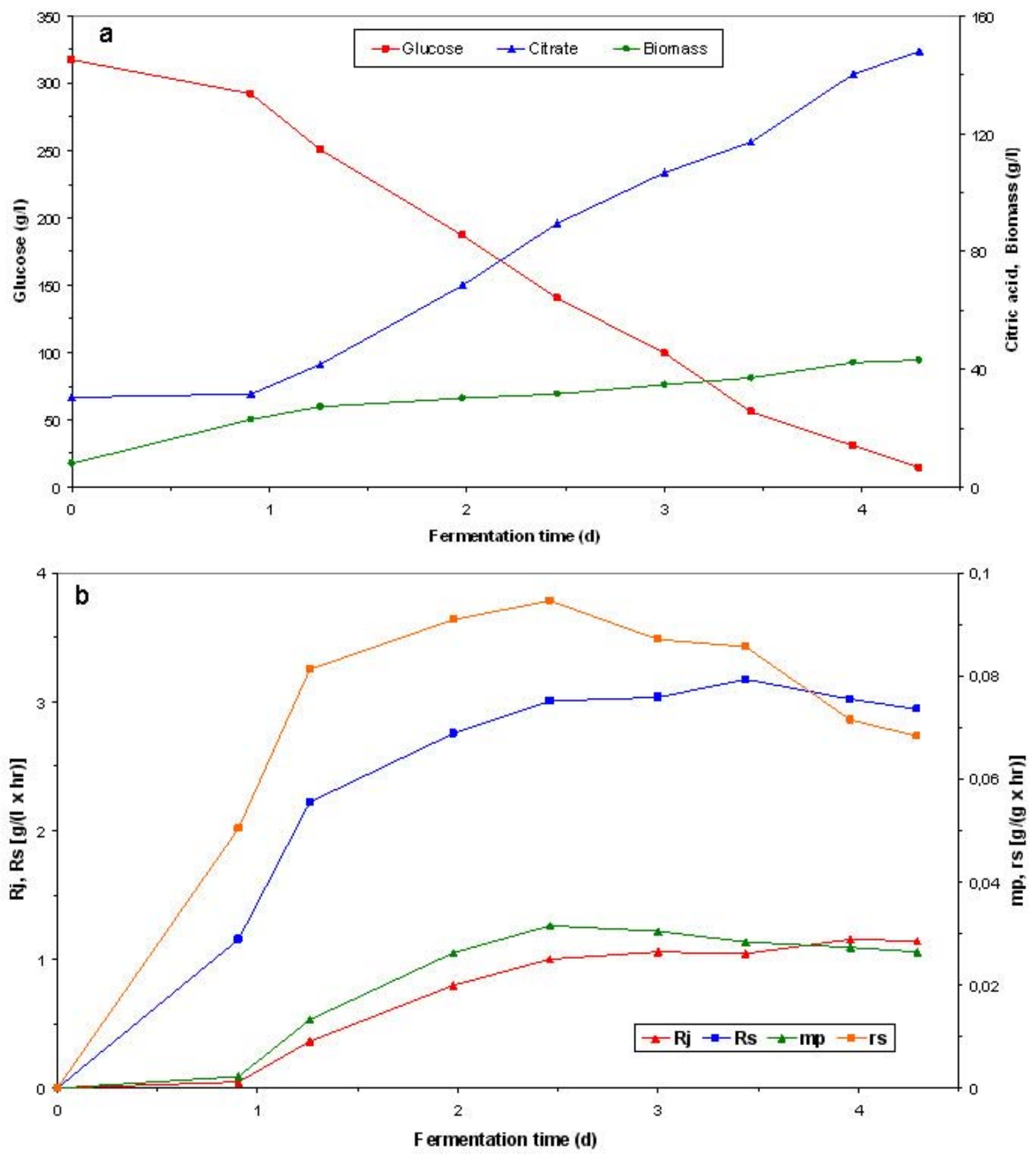

Figure 4. Repeated batch fermentation $\left(R B_{1}\right)$ of citric acid with Candida oleophila at $80 \%$ air saturation and increased phosphate concentration.

(a) Glucose, citric acid and biomass as a function of fermentation time.

(b) Formation rate of the generic product $(\mathrm{Rj})$, specific citric acid productivity $\left(\mathrm{m}_{\mathrm{p}}\right)$, glucose consumption rate (Rs) and specific glucose consumption rate $\left(\mathrm{r}_{\mathrm{s}}\right) ;\left(2.1 \mathrm{~g} / \mathrm{K} \mathrm{KH}_{2} \mathrm{PO}_{4}, 30^{\circ} \mathrm{C}\right.$ and $\left.\mathrm{pH} 5\right)$.

(Anastassiadis et al. 1993; Anastassiadis et al. 1994; Anastassiadis et al. 2004). The eluent was able to use for longer time, because of eluent's high toxicity (no microbial growth occurred in the eluent). Sugars were detected using an RI detector (S4110/S 1000, Sykam Co., Germany).

\section{RESULTS}

Oxygen influence on continuous citric acid fermentation by Candida oleophila ATTC 20177 (var.)

During an extensive chemostat optimisation research program, continuous citric acid fermentation by $C$. oleophila,carried out applying an optimised fermentation medium and optimum temperature of $30^{\circ} \mathrm{C}$ and $\mathrm{pH} 4.5$, has 
been found to be strongly influenced by the air saturation, reaching highest values at $20 \%$ air saturation. Optimization experiments in chemostat are in generally carried out at a conversion lower than $80 \%$, in order to detect any possible differences occurring as a function of fermentation parameter, which is investigated. $98 \mathrm{~g} / \mathrm{l}$ of citric acid were continuously produced at a residence time of $54 \mathrm{hrs}(\mathrm{D}=$ $0.0185 \mathrm{~h}^{-1}$ ) with a ratio between citrate and isocitrate of 33.3 by the experiment's lowest steady state biomass concentration of about $18 \mathrm{~g} / \mathrm{l}$ and at lowest intracellular concentration of citrates. The highest biomass concentration of $29.62 \mathrm{~g} / \mathrm{l}$ was determined at $80 \%$ air saturation. A ratio between citrate and isocitrate higher than 27 was found along the entire range of air saturation that has been investigated (5-133\% air saturation). With increasing air saturation isocitrate concentration increased lightly. The maximum formation rate of the generic product $\left(\mathrm{R}_{\mathrm{j}}\right)$ of $1.81 \mathrm{~g} /(1 \mathrm{x} \mathrm{hr})$ and specific citric acid productivity $\left(\mathrm{m}_{\mathrm{p}}\right)$ of $0.1 \mathrm{~g} /(\mathrm{g} \times \mathrm{hr})$ were also determined at $20 \%$ air saturation. Highest $\mathrm{Rj}$ for isocitric acid of $55.6 \mathrm{mg} /(\mathrm{l} \mathrm{x} \mathrm{hr})$ and $\mathrm{m}_{\mathrm{p}}$ of $0.99 \mathrm{mg} /(\mathrm{g} \mathrm{x} \mathrm{hr})$ were identified at $50 \%$ instead. Only $77.4 \mathrm{~g} / \mathrm{l}$ of citric acid $(78.7 \%)$ were produced at $80 \%$ and $77.2 \mathrm{~g} / \mathrm{l}(78.6 \%)$ at $5 \%$ air saturation (Table 1). Up to $150 \mathrm{~g} / \mathrm{l}$ were produced continuously at longer residence times using C. oleophila (Anastassiadis et al. 1993; Anastassiadis, 1994; Anastassiadis et al. 1994; Anastassiadis et al. 2001).

\section{Batch and continuous repeated batch fermentation of citric acid by Candida oleophila ATTC 20177 (var.)}

Initialisation batch citric acid fermentation by $C$. oleophila ATCC 20177 (var.). Initially, the first batch fermentation was inoculated with a $10 \%$ inoculum of a 2 day culture (grown on basal medium at $30^{\circ} \mathrm{C}$ and $200 \mathrm{rpm}$ ) and it was carried out at $20 \%$ air saturation. As Figure 1 shows, starting with a biomass of $0.038 \mathrm{~g} / \mathrm{l}$ and after a lag phase of about one day, biomass increased logarithmically until reaching $20.33 \mathrm{~g} / \mathrm{l}$ at 2.27 days and $17.08 \mathrm{~g} / \mathrm{l}$ citric acid. A biomass of $25.47 \mathrm{~g} / 1,134.3 \mathrm{~g} / \mathrm{l}$ citric acid and 4.4 $\mathrm{g} / \mathrm{l}$ glucose were obtained at fermentation end after 7.4 days, with a ratio between citrate and isocitrate of 15.8 and a selectivity of above $40 \%$. Citric acid secretion started after about 1.14 days showing a steeper coarse entering post-logarithmic growth (2.27 days) and during transition (higher production) (2.27-3.19 days) and stationary growth phase (3.19-6 days), holding as long as 6 days, reaching $121.33 \mathrm{~g} / \mathrm{l}$ citric acid and $20.2 \mathrm{~g} / \mathrm{l}$ residual glucose. The initiation of citric acid secretion started a few hours after the complete depletion of nitrogen in the medium and was caused by the intracellular nitrogen limitation (following a transition phase) and the reduction of cellular nitrogen content that resulted in intracellular $\mathrm{NH}_{4}{ }^{+}$accumulation as has been described in Anastassiadis et al. 2002.

The integral formation rate (calculated from measurements of each particular point and from measurement at time zero) of the generic product $(\mathrm{Rj})$ and specific citric acid productivity $\left(\mathrm{m}_{\mathrm{p}}\right)$ reached highest values of $0.82 \mathrm{~g} /(1 \mathrm{x} \mathrm{hr})$ and $0.0324 \mathrm{~g} /(\mathrm{g} \times \mathrm{hr})$ at 6 days fermentation time. A decrease in glucose consumption rate (Rs) occurred each time, sequentially entering into the next growth phase, e.g. transition phase (from 1.68 to $1.64 \mathrm{~g} /(1 \mathrm{x} \mathrm{hr})$ at 2.369 days) or stationary phase (from 2.285 to $2.253 \mathrm{~g} /(1 \mathrm{x} \mathrm{hr}$ ) at 3.41 days). Finally, Rs reached $1.86 \mathrm{~g} /(1 \mathrm{x} \mathrm{hr})$ at the end of fermentation after 7.42 days. The specific glucose consumption rate reached a maximum of $0.268 \mathrm{~g} /(\mathrm{g} \mathrm{x} \mathrm{hr})$ at 1.23 days (Figure 1).

Repeated batch fermentation at $80 \%$ air saturation $\left(\mathbf{R B}_{1}\right)$. Repeated batch fermentations were carried out at $\mathrm{pH}$ 5 and $80 \%\left(\mathrm{RB}_{1}\right)$ or pH 5 and $20 \%$ air saturation $\left(\mathrm{RB}_{2}\right)$ in order to investigate the influence of air saturation on batch citric acid production as a comparison with the continuous chemostat fermentation. Acceleration in biomass and citrate production was observed in all of repeated batch experiments, compared with the initial batch fermentations.

Figure 2 shows biomass and citric acid concentration at $80 \%$ air saturation $\left(\mathrm{RB}_{1}\right)$. Despite the very initial high glucose concentration of $336 \mathrm{~g} / \mathrm{l}$, the biomass increased after a very short lag phase, indicating the very high osmotolerance of yeast strains. A biomass concentration of $29.6 \mathrm{~g} / \mathrm{l}$ was determined after 1.93 days. Citric acid secretion started after about 0.56 days compared with more than 1 day in batch fermentation and was also excreted during the logarithmic growth. Following biomass formation, citric acid concentration increased continuously in a linear mode starting after a lag phase and the initiation of citric acid secretion at between 0.5 and 0.6 days, holding as long as glucose achieved a concentration of around 70 $\mathrm{g} / \mathrm{l}$. Fermentation started with an initial citric acid concentration of $25.51 \mathrm{~g} / \mathrm{l}$ and biomass concentration of $8.72 \mathrm{~g} / \mathrm{l}$ from previous repeated batch experiment and reached $166.5 \mathrm{~g} / \mathrm{l}$ and $34.28 \mathrm{~g} / \mathrm{l}$ after 4.58 days with a citrate/isocitrate ratio of 20 at a residual glucose concentration of $7.6 \mathrm{~g} / \mathrm{l}$, whilst $93.7 \mathrm{~g} / \mathrm{l}$ citric acid were already measured after 2.6 days of fermentation. Glucose was finally completely consumed at last measured point of 4.85 days. Thus, a time reduction of about 2 days was achieved, compared with the batch experiment.

The formation rate of the generic product $(\mathrm{Rj})$ as well as the specific citric acid productivity $\left(\mathrm{m}_{\mathrm{p}}\right)$ showed a continuing increase following accumulation of citric acid, until reaching a maximum of $1.283 \mathrm{~g} /(1 \mathrm{x} \mathrm{hr})$ at 4.01 days and of $0.0375 \mathrm{~g} /(\mathrm{g} \mathrm{x} \mathrm{hr})$ at 4.58 days, respectively. Rs reached highest value of $3.33 \mathrm{~g} /(1 \mathrm{x} \mathrm{hr})$ entering stationary phase after 2.56 days at a glucose concentration of $131.2 \mathrm{~g} / \mathrm{l}$. The specific glucose consumption rate reached a maximum of $0.112 \mathrm{~g} /(\mathrm{g} \mathrm{x} \mathrm{hr})$ at 1.81 days (Figure 2).

Repeated batch fermentation at $20 \%$ air saturation $\left(\mathbf{R B}_{\mathbf{2}}\right)$. As Figure 3 shows, in repeated batch experiment with $20 \%$ air saturation $\left(\mathrm{RB}_{2}\right)$ the biomass followed a similar course to $80 \%$ entering stationary phase after 2.69 2.86 days. A biomass of $28.7 \mathrm{~g} / \mathrm{l}$ was determined after 4.65 
days. A final biomass concentration of $28.82 \mathrm{~g} / \mathrm{l}$ was determined after 5.36 days, starting with a biomass of about $7.2 \mathrm{~g} / \mathrm{l}$ (Figure 3). 20\% air saturation resulted to lower productivity and concentration of citric acid, compared with $80 \%$. Citric acid secretion started after about 0.71 days $(33.9 \mathrm{~g} / \mathrm{l})$ and only $153.7 \mathrm{~g} / \mathrm{l}$ citric acid were obtained after 4.94 days with a citrate/isocitrate ratio of 19.2, starting with an initial concentration of $33 \mathrm{~g} / \mathrm{l}$ and reaching a final concentration of $157.58 \mathrm{~g} / \mathrm{l}$ at 5.36 days and a residual glucose of $1.9 \mathrm{~g} / \mathrm{l}$, starting with an initial glucose concentration of $336 \mathrm{~g} / \mathrm{l}$ (Figure 3).

The highest $\mathrm{Rj}$ of $2.91 \mathrm{~g} /(\mathrm{l} \mathrm{x} \mathrm{hr})$ and $\mathrm{m}_{\mathrm{p}}$ of $0.102 \mathrm{~g} /(\mathrm{g} \mathrm{x} \mathrm{hr})$ were found after the beginning of stationary phase at about 3 days. Rs showed, with exception of a decrease from 2.71 to $2.68 \mathrm{~g} /(1 \mathrm{x} \mathrm{hr})$ at 2.86 days, a regular continuous increasing tendency until reaching highest value of $2.91 \mathrm{~g} /(1$ $\mathrm{x} \mathrm{hr}$ ) after entering stationary phase at about 3 days and $145.7 \mathrm{~g} / \mathrm{l}$ glucose. Thereafter, Rs decreased continuously achieving $2.47 \mathrm{~g} /(1 \mathrm{x} \mathrm{hr})$ at the end of fermentation after 5.36 days. The highest specific glucose consumption rate $\left(\mathrm{r}_{\mathrm{s}}\right.$ ) of $0.134 \mathrm{~g} /(\mathrm{g} \mathrm{x} \mathrm{hr}$ ) was found at 1.67 days (Figure 3).

Repeated batch fermentation at $\mathbf{8 0 \%}$ air saturation and increased phosphate concentration $\left(\mathbf{R B}_{3}\right)$. In a further $\mathrm{RB}$ experiment $\left(\mathrm{RB}_{3}\right)$, performed at $\mathrm{pH} 5$ and $80 \%$ saturation, the concentration of $\mathrm{KH}_{2} \mathrm{PO}_{4}$ was increased from $1.4 \mathrm{~g} / \mathrm{l}$ to $2.1 \mathrm{~g} / \mathrm{l}$, based on medium optimisation carried out in chemostat experiments, in order to examine phosphate influence in relation to active transport system for citrate secretion and energy state of cells. Biomass increased enormously (20.5\%), just changing the concentration of only this medium compound, however no significant changes were observed in citrate productivity whereas final $m_{p}$ decreased substantially by about $28.5 \%$. A biomass of $43.14 \mathrm{~g} / \mathrm{l}, 147.9 \mathrm{~g} / \mathrm{l}$ citric acid and $14.5 \mathrm{~g} / \mathrm{l}$ residual glucose were determined in $\mathrm{RB}_{3}$ after 4.29 days (Figure 4). The highest Rs of $3.17 \mathrm{~g} /(1 \mathrm{x} \mathrm{hr})$ was found at 3.43 days and highest $\mathrm{m}_{\mathrm{p}}$ of $0.315 \mathrm{~g} /(\mathrm{g} \times \mathrm{hr})$ was determined at 2.46 days (Figure 4 ).

\section{DISCUSSION}

A new process for the production of citric acid in a continuous mode has been developed and presented here, that uses the filling and drain method. The experiments were repeated as long until the results achieved stable and reproducible values (a kind of steady state situation), reflecting the real situation of a series of sequential repeated batch experiments. The acceleration of fermentation can be explained by the higher starting biomass concentration in fermenter and by the adaptation of biomass to very high osmotic pressures (e.g. very high glucose or citric acid concentration). It seems very possible, that the biomass that sticks on the fermenter glass vessel can also influence the starting situation of fermentation, because it is difficult to avoid its entrance into fermenter broth during the filling procedure. In a series of repeated batch experiments, the very high citric acid concentrations were repeatedly achieved for about 20 times. No reduction had been observed in productivity, caused by the aging of cells, and the decrease in biosynthetic activity of cells, during the long cultivation time in repeated batch fermentations. The cells are revived any time the fermentation vessel is filled with a new fermentation medium.

In contrary to chemostat fermentations, growth and production are running independent from each other in batch operations. In batch process, a characteristic series of events is occurring during citric acid fermentation in yeasts, starting with the extracellular depletion of nitrogen (trophophase), followed up by a transition phase of a few hours (Stottmeister et al. 1986; Behrens et al. 1978, 1987; Anastassiadis 1994; Anastassiadis et al. 2002), which is characterised by the intracellular nitrogen limitation and the reduced nitrogen content in the cells (Briffaud and Engasser, 1979; Anastassiadis et al. 1993; Anastassiadis 1994; Moresi, 1994; Anastassiadis et al. 2002). The raising intracellular $\mathrm{NH}_{4}{ }^{+}$concentration (Anastassiadis et al. 2002), the increase of energy charge (Kleber and Schlee, 1987; Anastassiadis et al. 2005), cell differentiation and the vacuolisation of cells follow (Kozlova et al. 1981; Anastassiadis et al. 2002). Citric acid secretion starts a few hours after the complete depletion of nitrogen and is caused by the intracellular nitrogen limitation. In chemostat cultures of Candida oleophila, citric acid production is occurring under nitrogen limiting steady state conditions and at decreased cell nitrogen content as well (Anastassiadis et al. 2005). The active $\mathrm{pH}$ dependent transport system and citrate secretion by the specific active transport system are induced entering the idiophase (Anastassiadis et al. 1993; Anastassiadis 1994; Anastassiadis et al. 1994; Anastassiadis et al. 2001; Anastassiadis et al. 2002; Anastassiadis et al. 2005). Furthermore, respiration rate has been reported to decrease when nitrogen source becomes completely exhausted (Wentworth and Cooper, 1996). The intracellular nitrogen limitation has been shown to be the most important factor that triggers out citric acid secretion, although high intracellular citric and isocitric concentrations occurred under non production conditions, before the induction of secretion by a specific active transport system (Anastassiadis et al. 2002). The iron effect on continuous citric acid fermentation was optimized in details and will be published in a separate paper. Increasing iron concentration promoted biomass formation instead of citrate secretion. The best results were obtained without any addition of iron into fermentation medium.

Air saturation has been found to have a very strong influence on continuous, batch and repeated batch fermentation of citric acid, indicating the importance of oxygen demand and oxygen mass transfer. The oxygen mass transfer is connected with Kla-value, which means the volumetric mass transfer coefficient of oxygen and which is strongly influenced by the viscosity of fermentation broth, aeration rate, agitation rate, temperature, the size of air 
Table 2. Comparison between previous and present results with literature values regarding citric acid production by fungi and yeasts.

\begin{tabular}{|c|c|c|c|c|c|}
\hline Reference & Microorganism & $\begin{array}{l}\text { RT or time } \\
\text { (h) }\end{array}$ & $\begin{array}{c}R j \\
(\mathrm{~g} / \mathrm{l} \times \mathrm{hr})\end{array}$ & $\begin{array}{c}\text { YP/S (\%) } \\
(g / g)\end{array}$ & $\begin{array}{c}\text { Citrate } \\
(g / I)\end{array}$ \\
\hline $\begin{array}{l}\text { Briffaud and Engasser, } \\
1979\end{array}$ & $\begin{array}{c}\text { Saccharomycopsis } \\
\text { lipolytica }\end{array}$ & $\begin{array}{l}200 \mathrm{hrs} \\
\text { (batch) }\end{array}$ & $\begin{array}{c}0.48 \\
0.7\end{array}$ & 75 & 95 \\
\hline $\begin{array}{l}\text { Enzminger and Asenjo, } \\
1986\end{array}$ & S. lipolytica & $\begin{array}{l}66 \mathrm{hrs} \\
\text { (batch) }\end{array}$ & 1.16 & 86 & 75 \\
\hline Tisnadjaja et al. 1996 & Candida guilliermondii & $\begin{array}{c}\text { Free cells } \\
110 \mathrm{hrs} \\
\text { Immobilized }\end{array}$ & 0.10 & 29 & 11.2 \\
\hline $\begin{array}{l}\text { Kristiansen and Charley, } \\
1981\end{array}$ & A. foetidus & $13 \mathrm{hrs}$ RT & 0.43 & - & 6.5 \\
\hline $\begin{array}{l}\text { Kristiansen and Sinclair, } \\
1979\end{array}$ & A. niger & $13 \mathrm{hrs}$ RT & 1.99 & & $\sim 26$ \\
\hline Roukas and Harvey, 1988 & A. niger & $83 \mathrm{hrs}$ RT & 0.058 & - & 4.8 \\
\hline $\begin{array}{l}\text { Previous and present } \\
\text { work } \\
\text { Continuous } \\
\text { Batch } \\
\text { Repeated batch }\end{array}$ & $\begin{array}{l}\text { Candida oleophila } \\
\text { ATCC } 20177 \text { (var.) }\end{array}$ & $\begin{array}{c}63 \text { hrs RT } \\
54-56 \text { hrs } \\
80-110 \text { hrs } \\
7.4 \text { days } \\
4.85 \text { days }\end{array}$ & $\begin{array}{c}1.98 \\
1.77-2.23 \\
1.8-1.43 \\
1.5\end{array}$ & $\begin{array}{l}>70 \\
75 \\
<70\end{array}$ & $\begin{array}{c}127 \\
98-125 \\
142-150 \\
131.8 \\
167\end{array}$ \\
\hline
\end{tabular}

bubbles etc. Most of published works in literature are carried out at unknown air saturation or dissolved oxygen concentration. In present work the air saturation was controlled, enabling the reproduction of results in future studies. The effect of air saturation was significant, resulting in differences regarding citric acid productivity of more than $20 \%$, which would influence the costs of an industrial fermentation process enormously. Moreover, the product yield and product selectivity are also strongly influenced by the air saturation. In the case of chemostat cultures, a very high glycolytic flow rate was achieved at $20 \%$ air saturation, meaning that a kind of a Crabtree effect was attained in this case, simulating an anaerobic glycolytic pathway under aerobic conditions. The formation rate of the generic product strongly coincided with the ratio between ATP and ADP at varying the $\mathrm{pH}$. The excessive energy gained by the substrate phosphorylation (high energy charge) is used promoting the active secretion of citric acid by the $\mathrm{pH}$ dependent active transport system (Anastassiadis and Rehm, 2005). Citric acid excretion, which starts after the exhaustion of nitrogen source and the intracellular nitrogen limitation, is promoted in repeated batch experiments in case of $80 \%$ air saturation, assuming a higher ATP level (low AMP content in cell) that has been found to closely correspond to stronger citric acid excretion by specific active transport system, found at optimum $\mathrm{pH}$ in C. oleophila (Anastassiadis et al. 2005; Anastassiadis and Rehm 2005).

Citric acid fermentation by yeasts as well as fungi is an aerobic process, strongly depending on oxygen supply and air saturation in fermenter. An excess of oxygen is required during the entire citric acid fermentation, whereby even short time interruptions of oxygen supply can cause irreversible changes in production ability or complete production lost (Rehm, 1980; Stottmeister and Hoppe, 1991; Sakurai et al. 1996). In contrary to continuous citric acid fermentation by $C$. oleophila displaying an optimum air saturation of $20 \%, 80 \%$ saturation has been found to result to higher productivity and selectivity in batch as well as repeated batch process instead (present work). A strong decrease in specific activities was found at air saturations lower or higher than $20 \%$, and a $\mathrm{m}_{\mathrm{p}}$ almost twice times higher was determined at $20 \%$ saturation (lower biomass concentration) compared with $80 \%$ (Anastassiadis et al. 1993; Anastassiadis, 1994; Anastassiadis et al. 1994).

The very high citrate/isocitrate ratio that was achieved by C. oleophila through a sophisticated process and medium optimisation is comparable with those that have been reached by high ratio mutant yeast strains (Akiyama et al. 1972; Akiyama et al. 1973a; Akiyama et al. 1973b). Alternatively, $167 \mathrm{~g} / \mathrm{l}$ citric acid were reached in continuous mode of repeated batch fermentations with the fill and drain technique after about 4.85 days at $80 \%$ air saturation, compared with only $157.6 \mathrm{~g} / \mathrm{l}$, which were achieved after about 5.4 days at $20 \%$. In every repeated batch run, cell growth and citric acid secretion started with a shorter lagphase compared with batch operations, reducing enormously the total fermentation time. The lag phase is strongly influenced by the osmotic pressure at the very high glucose concentrations higher than $350 \mathrm{~g} / \mathrm{l}$, which would strongly inhibit the growth of most of microorganisms. Increase of phosphate concentration resulted only in a higher biomass concentration. Wentworth and Cooper (1996) reported about the advantages of synchronous cell growth in an efficient self-cycling two-stage fed-batch fermentation process, eliminating down times that are necessary for cleaning, sterilization and inoculation, and enhancing biomass formation rate, in comparison with 
conventional non-synchronous growth. There is a wide distribution of cell ages and only a fraction of the cells is being at the appropriate production state at the initiation of second fermentation phase. A maximum concentration of $11 \mathrm{~g} / \mathrm{l}$ was reached in shake flasks for an initial glucose concentration of $50 \mathrm{~g} / \mathrm{l}$ in the second fermentation stage (Wentworth and Cooper, 1996). Tisnadjaja et al. 1996 reported about beneficial cell immobilization of $C$. guilliermondii from the viewpoint of recovery and reuse of cells in repeated batch cultures, reaching similar citric acid concentration, productivity and citrate yield, compared with batch cultures utilizing freely suspended cells.

A little information can be found in literature regarding continuous citric acid production, in especially for $A$. niger process. Because for long time it has been thought that citric acid couldn't be produced in a continuous mode, this type of data for microbial growth and continuous production of citric acid on glucose or other carbon sources is rather rare in literature. For instance, looking in the internet about 15,200 results was found as compared with 89 for chemostat (Anastassiadis et al. 2005; Anastassiadis and Rehm, 2005). Previous studies have demonstrated the feasibility of a semi-continuous production of citric acid by Aspergillus niger (Lesniak and Stawicki, 1979) and lowrate continuous production of citric acid under nitrogenlimiting conditions by yeast Candida lipolytica (Aiba and Matsuoka, 1979; Kim et al. 1987; Klasson et al. 1989). Kristiansen and Sinclair, 1979 reported about a continuous single-stage citric acid fermentation under nitrogen limitation using $A$. foetidus, reaching citric acid concentrations up to $40 \mathrm{~g} / \mathrm{l}$ at dilution rates between 0.04 and $0.21 \mathrm{~h}^{-1}$ (4.76-25 hrs RT) and a maximum productivity of $0.43 \mathrm{~g} /(1 \mathrm{x} \mathrm{hr})$ at a dilution rate of $0.075 \mathrm{~h}^{-1}(13.3 \mathrm{hrs}$ RT). Wieczorek and Brauer, 1998 reported about a four stage process for the continuous citric acid production using A. niger, recirculating fermentation broth, that includes the fermentation, extraction, reextraction and the product stage. A considerable increase in productivity in a continuous single-stage process using A. niger, compared with the batch process, has also been reported by Kristiansen and Charley, 1981, however only $26.5 \mathrm{~g} / \mathrm{l}$ of citric acid were produced at a RT of $13 \mathrm{hrs}$ and $\mathrm{pH}$ 1.7. In comparison, about $125 \mathrm{~g} / \mathrm{l}$ citric acid were continuously produced by $C$. oleophila in chemostat cultures at $54 \mathrm{hrs}$ RT, up to $150 \mathrm{~g} / \mathrm{l}$ citric acid at higher RT and about $170 \mathrm{~g} / \mathrm{l}$ in repeated batch experiments (Anastassiadis et al. 1993; Anastassiadis, 1994; Anastassiadis et al. 1994; Anastassiadis et al. 2001).

Table 2 compares the new developed processes with literature reports. Details of fermentation processes used by companies are closely guarded and hold as trade secrets and therefore a little information is available regarding processes used for large-scale production of citric acid. About 150-180 g/l citric acid are commonly produced discontinuously in industry within 5-6 days using high selected Aspergillus niger mutant strains of several generations, which also require additional down times for the induction of sporulation, sporulation, spore cultivation in a smaller fermenter, preparation of fermenter and finally inoculation of large production fermenter. The values of citric acid concentration and formation rate of the generic product that have been obtained in continuous mode in our present and previous works using $C$. oleophila are comparable with productivities that are found in literature reports, favouring the use of the developed continuous processes for the industrial production of citric acid in future. In view of economical aspects, the continuous production of citric acid using yeasts shows many advantages, compared with the traditional industrial discontinuous processes of the last 100 years, employing selected mutant strains (several generations of classical mutagenesis) of Aspergillus niger. The higher productivities of presented continuous processes and the very high citric acid concentrations that have been reached appear suitable and commercially valid for industrial purposes, which can stand in today's strong competition in citric acid industry, requesting smaller fermenters in opposite to very large fermenters of $500-1000 \mathrm{~m}^{3}$ that are used in industry today. The current presented process has also been successfully carried out in a pilot fermentation scale of 1000 litres in industry. The use of yeasts instead of moulds in citric acid production also represents an innovative approach, which is also of human health. The use of Aspergillus niger represents a potential of toxic compounds presence (micotoxins), whereas yeasts of Candida oleophila don't have a potential for the production of toxic compounds.

From economic point of view, integral $\mathrm{Rj}$ and $\mathrm{m}_{\mathrm{p}}$ are two of the most important specific fermentation parameters, determining the goodness of a fermentation process and a microbial system. A higher final integral Rj of $1.213 \mathrm{~g} /(1 \mathrm{x}$ hr) was reached at $80 \%$ air saturation compared with only $0.968 \mathrm{~g} /(1 \mathrm{x} \mathrm{hr})$ at $20 \%$ that corresponds to a productivity increase of about $20 \%$. A final integral specific citric acid productivity of $0.0354 \mathrm{~g} /(\mathrm{g} \times \mathrm{hr})$ determined at $80 \%$ saturation is only at about $5.1 \%$ higher, compared with $20 \%$ saturation that reached $0.0336 \mathrm{~g} /(\mathrm{g} \mathrm{x} \mathrm{hr})$. It also reflects the higher biomass concentration of around $34 \mathrm{~g} / \mathrm{l}$ that has been measured at $80 \%$, compared with about $28.8 \mathrm{~g} / \mathrm{l}$ (it means a stronger nitrogen limitation as well), which was determined at $20 \%$ and the compensating effect between biomass concentration and $\mathrm{m}_{\mathrm{p}}$, determining the formation rate of the generic product $\mathrm{Rj}$. Compared with the continuous fermentation process, where growth and production are running simultaneously, influencing each other ( $\mathrm{Rj}$ results from a compensation effect between $\mathrm{m}_{\mathrm{p}}$ and biomass concentration), in batch operations they are running independent from each other.

\section{CONCLUDING REMARKS}

Summarizing present and previous findings, important events found in yeast process would include nitrogen depletion in fermentation medium, intracellular decrease of nitrogen content $(\sim 4 \%)$, elevation of $\mathrm{NH}_{4}{ }^{+}$concentration in the cell $(\sim 37.4 \mathrm{mM})$, enhanced energy charge in cells 
displaying a maximum at optimum fermentation conditions (e.g. $\mathrm{pH}$, air saturation and temperature), induction of specific transport system for citrate secretion, citrate secretion by active transport system, fine tuning regulation of citrate secretion by ATP, $\mathrm{CO}_{2}$, residence time etc. Furthermore, medium optimization (e.g. iron limitation etc.) increased citric acid production enormously. In view of economical aspects, continuous chemostat and repeated batch production of citric acid by yeasts seems to have many advantages compared with the traditional discontinuous industrial processes of the last 100 years utilizing Aspergillus niger. The presented results on citric acid production from glucose by yeast are the best reported in the international bibliography.

\section{ACKNOWLEDGMENTS}

I thank Professor Dr. U. Stottmeister, Mrs. E. Weissbrodt (UFZ Ctr. Envtl. Res. Leipzig-Halle, Germany) and Prof. Dr. Christian Wandrey (Institute of Biotechnology 2 of Research Center Jülich, RCJ, Germany) for their helpful advices and support.

\section{DECLARATION}

The experiments of the present manuscript comply with the currant laws of the country Germany (Institute of Biotechnology 2 of Research Centre Jülich 2 (RCJ); formerly known as Nuclear Research Centre Jülich (KFA), where the experiments were performed.

\section{REFERENCES}

AIBA, Shuichi. and MATSUOKA, Masayoshi. Identification of metabolic model: citrate production from glucose by Candida lipolytica. Biotechnology and Bioengineering, 1979, vol. 21, no. 8, p. 1373-1386.

AKIYAMA, S.-I.; SUZUKI, T.; SUMINO, Y.; NAKAO, $\mathrm{Y}$. and FUKUDA, $\mathrm{H}$. Induction and citric acid productivity of fluoroacetate-sensitive mutant strains of Candida lipolytica.Agricultural and Biological Chemistry, 1973a, vol. 37, no. 4, p. 879-884.

AKIYAMA, S.-I.; SUZUKI, T.; SUMINO, Y.; NAKAO, Y. and FUKUDA, H. Relationship between aconitase hydratase activity and citric acid productivity in fluoroacetate-sensitive mutant strain of Candida lipolytica. Agricultural and Biological Chemistry, 1973b, vol. 37, no. 4, p. 885-888.

AKIYAMA, S.-I.; SUZUKI, T.; SUMINO, Y.: NAKAO, Y. and FUKUDA, H. Production of citric acid from $n$ paraffins by fluoroacetate-sensitive mutant strains of Candida lipolytica. In: Proceedings of the IV International Fermentation Symposium: Fermentation Technology Today. (19 ${ }^{\text {th }}-25^{\text {th }}$ March, 1972, Kyoto, Japan). 1972, p. 613-617.
ANASTASSIADIS, Savas, WANDREY, Christian and REHM, Hans-Jürgen. Continuous citric acid fermentation by Candida oleophila under nitrogen limitation at constant $\mathrm{C} / \mathrm{N}$ ratio. World Journal of Microbiology and Biotechnology. World Journal of Microbiology and Biotechnology, 2005, vol. 21, no. 5, p. 695-705.

ANASTASSIADIS, Savas and REHM Hans-Jürgen. Continuous citric acid secretion by a high specific $\mathrm{pH}$ dependent active transport system in yeast Candida oleophila ATCC 20177. Electronic Journal of Biotechnology, 2005, vol. 8, no. 2, p. 147-162.

ANASTASSIADIS, Savas; AIVASIDIS, Alexander and WANDREY, Christian. Citric acid production by Candida strains under intracellular nitrogen limitation. Applied Microbiology Biotechnology, 2002, vol. 60, no. 1-2, p. 8187.

ANASTASSIADIS, Savas; AIVASIDIS, Alexander and WANDREY, Christian. Process for the continuous production of citric acid by fermentation. US Patent No. 08/208,123, August 3 1994, 2001.

ANASTASSIADIS, Savas; AIVASIDIS, Alexander and WANDREY, Christian. Process for the production of gluconic acid with a strain of Aureobasidium pullulans (De Bary) Arnaud. US Patent No. 5,962,286, October 5, 1999).

ANASTASSIADIS, Savas. Zymotiki methodos gia tin sinechi paragogi tou kitrikou oxeos; Process for the continuous production of citric acid by fermentation. Greek Patent No. 940100098, February 24 1994, 1994.

ANASTASSIADIS, Savas; AIVASIDIS, Alexander and WANDREY, Christian. Fermentationsverfahren zur kontinuierlichen Citronensäuregewinnung. (Process for the continuous production of citric acid by fermentation). Austrian Patent No. 473/94, July 3 1994, 1994.

ANASTASSIADIS, Savas; AIVASIDIS, Alexander and WANDREY, Christian. Fermentationsverfahren zur kontinuierlichen Citronensäuregewinnung(Process for the continuous production of citric acid by fermentation), German Patent No. P 4317 488.4-09, March 181993, 1993.

ANASTASSIADIS, Savas. Determination of organic acids, especially citric acid and isocitric acid, in fermentation solutions and fruit juices. In: HPLC Applications, MACHEREY-NAGEL GmbH \& Co. KG (Düren, Germany), Application, 1993, no. 8, p. 4.

ANTONUCCI, S.; BRAVI, M.; BUBBICO, R.; Di MICHELE, A. and VERDONE, N. Selectivity in citric acid production by Yarrowia lipolytica. Enzyme and Microbial Technology, 2001, vol. 28, no. 2-3, p. 189-195.

ARZUMANOV, T.E.; SIDOROV, I.A.; SHISHKANOVA, N.V. and FINOGENOVA, T.V. Mathematical modeling of 
citric acid production by repeated batch culture. Enzyme and Microbial Technology, 2000, vol. 26, no. 9-10, p. 826833.

BUBBICO, R.; LO PRESTI, S.; BRAVI, M.; MORESI, M. and SPINOSI, M. Repeated batch citrate production by Yarrowia lipolytica using yeast recycling by cross-flow microfiltration. Agro-Food Industry Hi-Tech, 1996, vol. 7, no. 2 , p. $35-38$.

BEHRENS, U.; THIERSCH, A.; WEISSBRODT, E. and STOTTMEISTER, U. Particularities in the kinetics of growth and citric-acid accumulation by Saccharomycopsis lipolytica. Acta Biotechnologica, 1987, vol. 7, no. 2, p. 179183.

BEHRENS, U.; WEISSBRODT, E. and LEHMANN, W. Zur Kinetik der Citronensäurebildung bei Candida lipolytica, Zeitschrift für Allgemeine Mikrobiologie, 1978, vol. 18 , no. 8 , p. 549-558.

BEHRENS, U.; HIRZEL, K. and SCHULZE, E. Enzymatische Untersuchungen zur Zitrat-IsozitratAkkumulation bei Hefen. Die Nahrung, 1977, vol. 21, no. 6, p. 525-530.

BRIFFAUD, J. and ENGASSER, M. Citric acid production from glucose. I. Growth and excretion kinetics in a stirred fermentor. Biotechnology and Bioengineering, 1979, vol. 21 , no. 11 , p. 2082-2092.

ENZMINGER, J.D. and ASENJO, J.A. Use of cell recycle in the aerobic fermentative production of citric acid by yeast. Biotechnology Letters, 1986, vol. 8, no. 1, p. 7-12.

FRANKE-RINKER, D. and BEHRENS, U. Enzymatische Untersuchungen zur Citrat-Isocitrat-Akkumulation bei Hefen. Die Nahrung, 1979, vol. 23, no. 9/10, p. 891-897.

FURUKAWA, T., MATSUYOSHI, T., MINODA, Y. and YAMADA, K. Fermentative production of citric acid from n-paraffins by yeast. Journal of Fermentation Technology, 1977, vol. 55, no. 4 , p. 356-363.

HATTORI, K.; HAKKO, K. and IMADA, O. Effect of ammonium ion on the ratio of citric acid to d-isocitric acid formed from n-paraffin. Journal of Fermentation Technology, 1974, vol. 52, no. 8, p. 542-550.

ILARIONOWA, W.I.; FINOGENOVA, T.W. and GLASUNOVA, L.M. Influence of cultivation conditions on the synthesis of citric and isocitric acids by Candida lipolytica on the hexadecane medium. Prikladnaya Biokhimiya i Mikrobiologiya, 1975, vol.X, p. 172-178.

KAMZOLOVA, S.V.; SHISHKANOVA, N.V.; MORGUNOV, I.G. and FINOGENOVA, T.V. Oxygen requirements for growth and citric acid production of Yarrowia lipolytica. FEMS Yeast Research, 2003, vol. 3, no. 2, p. 217-222.
KHAN, A.H. and GHOSE, T.K.Kinetics of citric acid fermentation by Aspergillus niger. Journal of Fermentation Technology, 1973, vol. 51, no.10, p. 734-741.

KIM, E.K. and ROBERTS, R.S. Rate equations for the vigorous stationary phase fermentation of citric acid by Saccharomycopsis lipolytica. Biotechnology and Bioengineering, 1991, vol. 37, no. 10, p. 985-988.

KIM, E.K.; AMBRIANO, J.R. and ROBERTS, R.S. Vigorous stationary phase fermentation. Biotechnology and Bioengineering, 1987, vol. 30, no. 6, p. 805-808.

KLASSON, T.K.; CLAUSEN, E.C. and GADDY, J.C. Continuous fermentation for the production of citric acid from glucose. Applied Biochemistry and Biotechnology, 1989, vol. 20/21, p. 491-505.

KLEBER, H.P. and SCHLEE, D. Biochemie I und II.,VEB Gustav Fischer Verlag Jena, 1987. p. 99-103, 112-113, 225231.

KOZLOVA, T.M.; MEDVEDEVA, G.A.; GLAZUNOVA, L.M. and FINOGENOVA, T.V. Structural changes in the cells of Candida lipolylica in the biosynthesis of citric acid. Mikrobiologiya, 1981, vol. 50, no. 3, p. 508-514.

KRISTIANSEN, B. and CHARLEY, R.C. Continuous process for production of citric acid. Advances in Biotechnology, 1981, vol. 1, p. 221-227.

KRISTIANSEN, B. and SINCLAIR, C.G. Production of citric acid in continuous culture. Biotechnology and Bioengineering, 1979, vol. 21, no. 2, p. 297-315.

KRISTIANSEN, B. and SINCLAIR, C.G. Production of citric acid in batch culture. Biotechnology and Bioengineering, 1978, vol. 20, no. 11, p. 1711-1722.

KUBICEK, C.P.; ZEHENNTGRUBER, O.; El-KALAK, H. and RÖHR, M. Regulation of citric acid production by oxygen: Effect of dissolved oxygen tension on adenylate levels and respiration. European Journal of Applied Microbiology and Biotechnology, 1980, vol. 9, p. 101-117.

LESNIAK, W. and STAWICKI, S. Semi-continuous fermentation of citric acid by submerged fermentation. Acta Alimentaria Polinica, 1979, vol. 29, no. 4, p. 365-376.

LI, Y.; HUGENHOLTZ, J.; CHEN, J. and LUN, S.-Y. Enhancement of pyruvate production by Torulopsis glabrata using a two-stage oxygen supply control strategy. Applied Microbiology and Biotechnology, 2002, vol. 60, no. 1-2, p. 101-106.

LOZINOV, A.B. and FINOGENOVA, T.V. Einfluß der Limitation des Wachstums von Hefen auf den oxidativen Stoffwechsel und die Produktsynthese. Acta Biotechnologica, 1982, vol. 2, no. 4, p. 317-324. 
MARCHAL, R.; CHAUDE, O. and METCHE, $M$. Production of citric acid from $n$-paraffins by Saccharomycopsis lipolytica: kinetics and balance of the fermentation. European Journal of Applied Microbiology,1977, vol. 4, no. 2, p. 111-123.

MAYILVAHANAN, D.; ANNADURAI, G.; RAJU, V.; CHELLAPANDIAN, M.; KRISHNAN, M.R.V. and JAYARAMAN, K. Citric acid production. Part 1: Strategies for reduction in cycle time for targeted yields. Bioprocess and Biosystems Engineering, 1996, vol. 15, no. 6, p. 323-326.

MORESI, M. Effect of glucose concentration on citric acid production by Yarrowia lipolytica. Journal of Chemical Technology and Biotechnology, 1994, vol. 60, no. 4, p. 387395.

OKOSHI, H.; SATO, S.; MUKATAKA, S. and TAKAHASHI, J. Citric acid production by Candida tropicalis under high dissolved oxygen concentrations. Agricultural and Biological Chemistry, 1987, vol. 51, no. 1, p. 257-258.

REHM, H.-J. Industrielle Mikrobiologie, 2. Aufl., Springer Verlag, Berlin, Heidelberg, New York, 1980.

ROUKAS, T. and HARVEY, L. The effect of $\mathrm{pH}$ on production of citric and gluconic acid from beet molasses using continuous culture. Biotechnology Letters, 1988, vol. 10 , no. 4, p. 289-294.

SAKURAI, A.; IMAI, H. and SAKAKIBARA, M. Effect of oxygen tension on citric acid production by surface culture. Journal of Fermentation and Bioengineering, 1996, vol. 82 , no. 5 , p. $519-521$.

STOTTMEISTER, U. and HOPPE, K. Organische Genußsäuren. In: RUTTLOFF, H. ed. Lebensmittelbiotechnologie, Entwicklungen und Aspekte, 1. Auflage, Akademie Verlag, Berlin, Germany, 1991, p. 516547.

STOTTMEISTER, U.; BEHRENS, U.; WEISSBRODT, E.; WEIZENBECK, E.; DÜRESCH, R.; KAISER, M.; NÖLTE, D.; RICHTER, H.-P.; SCHMIDT, J.; KOCHMANN, W.; MAY, U.; KREIBICH, G. and SCHÖPPE, G. Patentschrift DD 239610 A1, (ISSN 04336461), 1986.

STOTTMEISTER, U.; BEHRENS, U. and GÖHLER, W. Einfluß des Sauerstoffpartialdrucks auf die Citronensäuresynthese durch Saccharomycopsis lipolytica aus n-Paraffinen. Zeitschrift für Allgemeine Mikrobiologie, 1981, vol. 21, no. 9, p. 677-687.

TABUCHI, T. Relationships between citrate fermentation and cell propagation in Candida lipolytica. Nihon-nogeikagaku-kaishi (Tokyo), Journal Agricultural Chemical Society of Japan, 1973, vol. 47, no. 8, p. 479-484.
TISNADJAJA, Djadjat; GUTIERREZ, Noemi, A. and MADDOX, Ian $\mathrm{S}$. Citric acid production in a bubblecolumn reactor using cells of the yeast Candida guilliermondii immobilized by adsorption onto sawdust. Enzyme and Microbial Technology, 1996, vol. 19, no. 5, p. 343-347.

WENTWORTH, S.D. and COOPER, D.G. Self-cycling fermentation of citric acid producing strain of Candida lipolytica. Journal of Fermentation and Bioengineering, 1996, vol. 81, no. 5, p. 400-405.

WIECZOREK, S. and BRAUER H. Continuous production of citric acid with recirculation of the fermentation broth after product recovery, Part 2: Product recovery and recirculation of the fermentation broth. Bioprocess and Biosystems Engineering, 1998, vol. 18, no. 2, p. 75-77.

ZEHENTGRUBER, O.; KUBICEK, C.P. and RÖHR, M. Alternative respiration of Aspergillus niger. FEMS Microbiology Letters, 1980, vol. 8, no. 2, p. 71-74. 